IRA-International Journal of Management \& Social Sciences

ISSN 2455-2267; Vol.03, Issue 03 (2016)

Institute of Research Advances

http://research-advances.org/index.php/RAJMSS

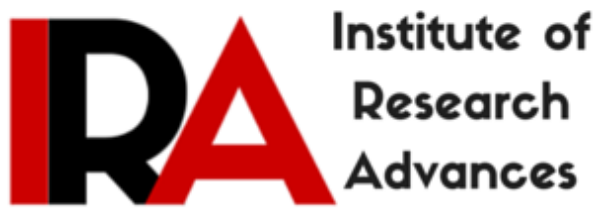

\title{
A Comprehensive Study of Selected Organized Retail Outlets at Gujarat: Human Resource Management Perspective
}

\author{
Dr. Sandip G. Prajapati \\ Assistant Professor \\ Department of Commerce and Business Management \\ Faculty of Commerce, \\ The Maharaja Sayajirao University of Baroda, Vadodara, India.
}

DOI: http://dx.doi.org/10.21013/jmss.v3.n3.p27

\section{How to cite this paper:}

Prajapati, S. (2016). A Comprehensive Study of Selected Organized Retail Outlets at Gujarat: Human Resource Management Perspective. IRA-International Journal of Management \& Social Sciences (ISSN 2455-2267), 3(3). doi:http://dx.doi.org/10.21013/jmss.v3.n3.p27

(C) Institute of Research Advances

\section{(cc) EY-NC}

This works is licensed under a Creative Commons Attribution-Non Commercial 4.0 International License subject to proper citation to the publication source of the work.

Disclaimer: The scholarly papers as reviewed and published by the Institute of Research Advances (IRA) are the views and opinions of their respective authors and are not the views or opinions of the IRA. The IRA disclaims of any harm or loss caused due to the published content to any party. 


\begin{abstract}
At the beginning of $21^{\text {st }}$ century, Indian retail sector is one of the fastest emerging sectors in India. Organized retail sector is growing at sound rate. Foreign players are also motivated to enter in to Indian market, which ultimately increase the competition at domestic market. Our Prime Minister Narendra modi declared 100\% FDI in retail sector. Due to this tuff competition and dynamics of consumer behavior organized retail store owners need to observe human force management at their work place. They need to observe motivation, compensation and performance evaluation systems and its impact over human force. Present paper attempt to analyze this by taking 200 samples from different cities of Gujarat. For this research descriptive single cross sectional research design was selected. Hypothesis and co relationship between two factors where done. In conclusion Workplace flexibility, flexi timings, job promotions opportunity, job enlargement \& enrichment, fairly monetary targets and salary \& gift or compensations will motivate the employees at organized retail sector.
\end{abstract}

Key Words: Human Resource Management, organizational Behavior at Retail Industry, Motivation, Job Satisfaction.

\title{
INTRODUCTION:
}

Indian market has high complexities in terms of a wide geographic spread and distinct consumer preferences varying by each region necessitating a need for localization even within the geographic zones. India has highest number of outlets per person (7 per thousand) Indian retail space per capita at $2 \mathrm{sq} f \mathrm{ft}$ $\left(0.19 \mathrm{~m}^{2}\right) /$ person is lowest in the world Indian retail density of 6 percent is highest in the world.1.8 million households in India have an annual income of over 45 lakh (US\$99,900). Present retail market in India is estimated to be US\$ 200 billion of which only 3\% (around US\$ 64 billion) is in the organized Sector. This organized retail secto̊n is poised for a takeoff. India is ranked second in the global retail development index out of 30 by AT Kearney with the organized retail segment growing at the rate of 25-30 per cent per annum. 85 per cent of organized retailing is taking place in India's urban areas while 66 per cent of it taking place in India's 6 main cities alone. The growth is much faster in south India than in northern states. The total retail market in south India is $\$ 94$ billion and

\section{Evolution of Retail Market in India}

In the beginning there were only kirana stores called Mom and Pop Stores, the Friendly neighborhood stores selling every day needs. In the 1980s manufacturer's retail chains like DCM, Gwalior Suitings, Bombay Dying, Calico, Titan etc started making its appearance in metros and small towns. Multi brand retailers came into the picture in the 1990s. In the food and FMCG sectors retailers like Food world, Subhiksha, Nilgris are some of the examples. In music segment Planet M, Music world and in books Crossword and Fountainhead are some others. Shopping Centers began to be established from 1995 onwards. A unique example was the establishment of margin free markets in Kerala. The millennium year saw the emergence of super markets and hyper markets. Now big players like Reliance, Bharti, Tatas, HLL, and ITC are entering into the organized retail segment. The big international retail bigwigs are waiting in the wings as the present FDI guidelines do not allow them to own retail outlets in the country. Table 1 shows the different phases in the growth of organized retailing in India. 


\begin{tabular}{|l|l|l|}
\hline \multicolumn{3}{|c|}{ Table : 1. Journey of Organized Retail in India } \\
\hline Year & Growth & Function \\
\hline 2000 & First Phase & Entry, Growth, Expansion, Top line focus \\
\hline 2005 & Second Phase & Range, Portfolio, Former options \\
\hline 2008 & Third Phase & $\begin{array}{l}\text { End to end supply chain management, Backend operation, } \\
\text { Technology, Process }\end{array}$ \\
\hline 2011 & Fourth Phase & M\&A, Shakeout, Consolidation, High investment \\
\hline Source : Ernst \&Young & \\
\hline
\end{tabular}

The drivers for the impending retail boom or ' $R$ ' revolution are many. These drivers are young population, high percentage of working women, as women are more avid shoppers compared to men folk, high visual media and increasing number of double income family who has more disposable income is another contributing factor for this phenomenon.

\section{LITERATURE REVIEW:}

Daniel C. Feldman and Barton A. Weitz conducted a research with a title called career plateaus in the sales force: understanding and removing blockages to employees wroth in November 1988. They found that sales forces productivity is going to improve with better understanding of career developments of the employee. Sales force management can be done and be successful by providing growth in responsibilities and performance of the sales employees over their entire couriers. Job enrichment and job enlargement will go to motivate them for good performance.

Same way George John, Allen M. Weiss, and Barton A. Weitz conducted research with a title -An Organization Coordination Model of Sales force compensation Plans in year 1987. The output of the research says only limited theoretical work has focused on the choice between different types of plans. Current study is different from agency theory by its assumption of risk-neutrality. Risk neutrality is quite possibly a counterfactual assumption, it permit us to address the impact of various factors like information asymmetry, opportunity costs, and contract enforcement difficulties.

Eli jones, Steven P. Brown, Andris A. Zoltners \& Barton A. Weitz conducted a research in 2005 with a title - The Changing Environment of Selling and Sales force management. This research paper discuss the implications of the major trends with respect to the sales and marketing; selecting, developing sales team, leadership, motivation, compensation and control technologies, CRM and team selling. This research spark the new idea for research to advance the theory and practice of sales force management.

Haris Sujan, Barton A. Weitz, Mita Sujan prepared a research paper in 1988 with titleincreasing Sales Productivity by getting sales people to work Smarter. The study found that developing sales force with high knowledge structure and motivation style is depends on the effective adoption by the company. Sales environment at the work place also result in the long term gain to the company and to sales team both. Sankar ganeshan conducted the research in 1993 with a title - negotiation strategy and the nature of channel relationship, he found that employees are motivated by their remuneration and challenging opportunity in their job. 


\section{Objective of the research}

To know how Employees are motivated at organized retail sector in the context of motivation, compensation and evaluation system.

\section{RESEARCH METHODOLOGY:}

The purpose behind this research is to do comparative analysis of sales management with respect to motivation, compensation and evaluation in organized retail industry in Gujarat. So descriptive research design was selected for conducting research, where researchers collect the information in the context of demographic and behavioral of the respondents. Researchers also include details like motivation, compensation and evaluation policies of the various retail players at Gujarat. Survey was conducted with the help of questionnaire; which includes structured open ended, close ended, and multiple choice questions and scaled respondents. Sampling techniques used was convenient sampling techniques. The sample includes respondents of various age groups. The sample size of the research was approximately 200 respondents. It was considered sufficient to analyze and interpret the data easily. After scrutiny of field data, the processing was done in Microsoft Excel. The entire multi choice options were pre-coded before being entered into the computer.

\section{INFERENTIAL ANALYSIS:}

H1: The authority given to employee as factor of motivation is depends on their Experience.

Here chi test $\mathrm{p}$ value is .026 , which is less than 0.05 . So null hypotheses should be rejected, It further enhances that the authority given to employee as factor of motivation is in depend on their Experience.

H2: The Fringe Benefits given to employee as factor of motivation is depends on their Experience.

Here chi test $\mathrm{p}$ value is .946 , which is more than 0.05 . So null hypotheses should be accepted, it further enhances that the Fringe Benefits given to employee as factor of motivation is depend on their Experience.

H3: The performance evaluation method of employee is depends on their education qualification.

Here chi test $p$ value is .725 , which is more than 0.05 . So null hypotheses should be Accepted, It further enhances that the performance evaluation method of employee is depends on their education qualification.

\section{Correlation between two factors:}

\begin{tabular}{|l|l|}
\hline Table 1. Correlation between two factors \\
\hline Authority & Experience \\
\cline { 2 - 2 } & \multicolumn{2}{|l|}{-0.14899} \\
\hline \multirow{4}{*}{ Job Promotion } & \multicolumn{2}{|l}{-0.90905} \\
\cline { 2 - 2 } & Age \\
\hline & \multicolumn{2}{|l|}{ Education } \\
\cline { 2 - 2 } & \multicolumn{2}{|c|}{-0.026341} \\
\hline
\end{tabular}


Here correlation between Authority given and Experience of employee is -0.14899 , which enhances that there is negative relation between authority of employee \& experience. The correlation between Commission given to employees and Income of employee is -0.90905 , which enhances that there is negative relation between Commission given to employees and Income of employee. The correlation between Job Rotation and Age of the employee is -0.06502 , which enhances that there is negative relation between Job Rotation and Age of the employee. The correlation between Job Promotion and Education of employee is -0.026341 , which enhances that there is negative relation between Job Promotion and Education of employee.

\section{DEMOGRAPHIC DETAILS:}

There is total 200 respondents (128 are male and 72 are female working employees), out of them 104 respondents are H.S.C. passed, in which highest 100 respondent are in the range of 18-30 in age category. 62 respondents are S.S.C passed, out of which 60 respondent are in the range of 18-30 in age category. 33 respondents are Graduate, out of which 29 respondent are in the rage of 18-30 in age category.

In the case of experience $50 \%$ of the employees having experience in the rage of 1-5 year and $49 \%$ of the employees having less than 1 year experience while only $1 \%$ of them having experience more than 5 year. If we analyze the family monthly income then 53\% of the employees having family income in the range of Rs. 100000 to 200000 and only $43 \%$ of the respondents fall in the range of 200000 to 300000 .

\section{DATA ANALYSIS \& FINDINGS:}

For conducting the research 200 sample ware selected and $100 \%$ of the respondents are from sales department. For non bias analysis equal number of the respondents was selected from each type of retail outlets. If we talking about experience then $56 \%$ of the respondents having the experience of 0 to 1 year, while only $2 \%$ of the respondents having experience more than 4 years.

Mostly friendly and co-operative working environment motivates the sales forces in retail stores. From the research it was found that $39 \%$ of the employee motivates from both the factored accordingly and 16\% centralized and 5\% decentralized and 1\% other factors affects of working environment. $74 \%$ of the employees are motivates and agree for having responsibilities and authority to exercise control for people and resources to motivates employees. $76 \%$ of the respondents are motivated with the help of workplace flexibility, flexi timings, telecommunicating and flexi work shifts. $69 \%$ of the employees are agreeing that team work motivates them. $70 \%$ of the respondents motivated by good job opportunity, $80 \%$ of the employees are agreed and $11 \%$ of them strongly agree for the level of agreement for the job objectives, responsibilities and new challenges motivate employees.

In the case of evaluation 93 respondents are evaluated on monthly bases, out of which 21 respondents are evaluated by Comparison with previous month performance, 37 respondents are evaluated by Comparison with other Employee, and 35 respondents are evaluated by Comparison with set standards. While 70 respondents are evaluated on weekly bases and 14 respondents are evaluated on annually. 59\% of the employees are agreed and $25 \%$ of them are strongly agreed for the level of agreement that job enrichment motivates employees. 57\% of the employees believes job enrichment motivate them. $63 \%$ of the employees believe salary given by the retail outlet owner is sufficient. $70 \%$ of the employees are agreed and $17 \%$ of them are strongly agreed for their level of agreement that they get fairly monetary targets. $47 \%$ of the employees are monthly evaluated on the basis of time 
interval while $35 \%$ of them are evaluated on weekly basis, only $7 \%$ are evaluated annually.

From inferential analysis following things revealed - from the chi square test researchers found that authority given to employee as factor of motivation is in depend on their Experience. The Fringe Benefits given to employee as factor of motivation is depend on their Experience. The performance evaluation method of employee is depends on their education qualification.

From the correlation between two factors analysis following things revealed - there is negative relationship between 1- Authority of employee \& experience, 2Commission given to employees and Income of employee, 3- Job Rotation and Age of the employee, 4- Job Promotion and Education of employee.

\section{CONCLUSION:}

Authority to exercise control and responsibilities as tool to motivate to work force is used by departmental store highly. Workplace flexibility, flexi timings as tool to motivate to work force is used by departmental store highly (See Annexure Table 2). Team Work as tool to motivate to work force is used by Super Market \& Specialty store highly. Job Promotion opportunity offered by organization as tool to motivate to work force is used by Super Market highly among all store types. A Job objective as tool to motivate to work force is used by Off-price retailer highly among all store types. Job Rotation for Employee's job as tool to motivate to work force is used by Large Store highly.

Job Enrichment for Employee's job as tool to motivate to work force is used by Large Store highly. Job Enlargement for Employee's job as tool to motivate to work force is used by both Super Market \& Specialty Store highly (See Annexure Table 3). Job Responsibilities as tool to motivate to work force is used by Large Store highly. Job Challenges as tool to motivate to work force is used by Large Store highly among all store types. An incentive as tool of Compensation Related Factors to Motivate Sales Force is highly used by Factory Outlet among all store types. Bonus as tool of Compensation Related Factors to Motivate Sales Force is highly used by Super Market highly. An attractive commission scheme as tool of Compensation Related Factors to Motivate Sales Force is highly used by Departmental Store highly (See Annexure Table 4). Salary \& gift as tool of Compensation Related Factors to Motivate Sales Force is highly used by Departmental Store.

Fairly Monetary Targets as Performance Evaluation Related Factors for Sales Force is highly used by Departmental Store Highly among all store types (See Annexure Table 5). Performance Evaluation on basis of Target Achievement as Performance Evaluation Related Factors for Sales Force is highly used by Departmental Store Highly among all store types.

\section{REFERENCES:}

[1] Areni, C. and Kim, D. (1993), the Influence of Background Music on Shopping Behavior, Classical Versus Top-Forty Music in a Wine Store. Advances in Consumer Research, Vol. 20, 336-340.

[2] Baker, J., Grewal, D. (1992), An experimental approach to making retail store environmental decisions, Journal of Retailing, Vol. 68, 445-60.

[3] Dash, J.F., Schiffman, L.G. and Berenson, C. (1976). Risk and personalityrelated dimensions of store choice, Journal of Marketing, Vol. 40, 32-9. 
[4] Kenhove, P., V., Wulf, K. D., and Walter, V. (1999), the impact of task definition on store-attributes saliencies and store choice, Journal of Retailing, Vol. 75 No. 1, 125-37.

[5] Kotler, P. (1974), Atmospherics as a marketing tool. Journal of Retailing, Vol.49, 48-64.

[6] Manish a Gupta, Mathew Joseph and. (2007). http://www.icrier.org. Retrieved september 20, 2011, from http://www.icrier.org/page.asp?MenuID=24\&SubCatId=175

[7] Marsh, H. (1999), Pop Stars of the Retail World. Marketing, January, pp 20 - 32.

[8] McGoldrick, P. (1990). Retail Marketing, Maidenhead: McGraw-Hill,

[9] Milliman, R. (1982), Using Background Music to Affect the Behavior of Supermarket Shoppers. Journal of Marketing, Vol. 46, 86-91.

[10] N.PRABHA, M. \&. (june 2008), A study on changing consumer preferences towards organized retailing from unorganized retailing, International Journal of Exclusive Management Research, 7-24.

[11] Radhakrishnan, K. (2003). www.hostursite.com/tag/dna/page/8/. Retrieved september 23, 2011, from: www.hostursite.com/tag/dna/page/8/

[12] Sen. (2000). papers.ssrn.com/sol3/Delivery.cfm?abstractid=994238. Retrieved September 23, 2011, from: papers.ssrn.com/sol3/Delivery.cfm?abstractid $=994238$

[13] Swapna Pradhan (2009), "Retail Management-Text \& Cases", Mc Graw Hill Education Pvt. Ltd, New Delhi.

[14] Yavas. U.(2001). "Purchase patterns and patronage motive: a correspondence analysis" http://www.emerald-library.com/ft

[15] "Consumer Behavior" By Leon G. Schiffman \& Lesile Lazar Kanuk, 8th Edition, Prentice Hall India.

[16] "Crafting and executing Strategy" By Arthur A. Thompson, Jr., A.J. Strickland III, John E. Gamble \& Arun K. Jain, 6th Edition, Tata Mc Graw Hill.

[17] "Marketing Research" An applied orientation By Naresh K. Malhotra and Satyabhusan Dash, 5th Edition, Prentice Hall India Publication

[18] "O" - Level made simple IT tools \& Applications by Satish Jain, Shashank Jain \& Dr. Madhulika Jain, 2nd Edition, and BPB Publications. 